Abstracted/indexed in Academic Search Complete, Agroforestry Abstracts, Asia Journals Online, Bangladesh Journals Online, Biological Abstracts, BIOSIS Previews, CAB Abstracts, Current Abstracts, Directory of Open Access Journals, EMBASE/Excerpta Medica, Google Scholar, HINARI (WHO), International Pharmaceutical Abstracts, Open J-gate, Science Citation Index Expanded, SCOPUS and Social Sciences Citation Index

ISSN: $1991-0088$

\title{
Effects of neferine on TGF- $\beta 1$ induced proliferation and gremlin expression in hepatic stellate cells
}

\author{
Xiaofei Li, Lianqing Lou, Shuang Wu, Yongxin Chen and Lingzhen Jin
}

Department of Infectious Diseases, Yiwu Central Hospital, Zhejiang 322 000, China.

\begin{tabular}{|c|c|}
\hline \multicolumn{2}{|l|}{ Article Info } \\
\hline Received: & 19 July 2012 \\
\hline Accepted: & 27 July 2012 \\
\hline Available Online: & 24 August 2012 \\
\hline \multicolumn{2}{|c|}{ DOI: 10.3329/bjp.v7i3.11298 } \\
\hline \multicolumn{2}{|c|}{$\begin{array}{l}\text { Cite this article: } \\
\text { Li X, Lou L, Wu S, Chen Y, Jin L. Ef- } \\
\text { fects of neferine on TGF- } \beta 1 \text { induced } \\
\text { proliferation and gremlin expression } \\
\text { in hepatic stellate cells. Bangladesh J } \\
\text { Pharmacol. 2012; } 7 \text { : 169-72. }\end{array}$} \\
\hline
\end{tabular}

\section{Abstract}

To clarify the possible molecular mechanism underlying the anti-fibrotic effect of neferine (Nef), we investigated the in vitro effects of Nef on the proliferation of hepatic stellate cells and expressions of gremlin, TGF- $\beta 1$ and a-SMA in these cells. TGF- $\beta 1$ had no influence on the proliferation of HSC-T6 cells $(p>0.05)$ but significantly up-regulated the mRNA and protein expressions of gremlin, TGF- $\beta 1$ and $\alpha-$ SMA in these cells $(p<0.005)$. Nef could inhibit the proliferation of HSC-T6 cells in a dose and time dependent manner, and down -regulate the mRNA and protein expression of gremlin, TGF- $\beta 1$ and a- SMA in these cells $(p<0.005)$. Nef is an effective drug that can inhibit the proliferation of hepatic stellate cells to improve the hepatic fibrosis. Gremlin involves in the occurrence and development of hepatic fibrosis and may become a promising target in the treatment of hepatic fibrosis.

\section{Introduction}

Hepatic fibrosis is a reversible pathological process of excessive deposition of extracellular matrix (ECM) in different chronic liver diseases, and the only way to progress into irreversible hepatic cirrhosis. To date, the activation of hepatic stellate cells (HSC) induced imbalance between the production of ECM and degradation of ECO has been considered as a key step in the occurrence and development of hepatic fibrosis (Tacke and Weiskirchen, 2010). Transforming growth factor- $\beta 1$ (TGF $\beta 1$ ) is the most potent cytokine that can promote the activation of HSCs, and gremlin is a downstream molecule of TGF- $\beta$. There is evidence showing that TGF- $\beta 1$ can specifically increase the protein and mRNA expression of gremlin, which has been found to be related to the fibrosis (Sethi et al., 2011). Thus, to block the above targets to inhibit the fibrosis is of great importance in clinical practice. Ding et al. (2011) confirmed that neferine (Nef), a dibenzyl isoquinoline alkaloid isolated from a Chinese medicinal herb (Nelumbo nucifera Gaertn), could inhibit the prolifera- tion of HSCs and promote their apoptosis in a mitochondrial-dependent apoptotic pathway exerting protective effect on hepatic fibrosis. However, no study has conducted to investigate the pathways involving in the anti-fibrotic effect of Nef. In the present study, the effects of Nef on the TGF- $\beta 1$ induced proliferation/ activation of HSCs (HSC-T6) collected from rats and on the expression of gremlin, TGF- $\beta 1$ and $\alpha-S M A$ in these cells were investigated aiming to explore the mechanism underlying the anti-fibrotic effect of Nef.

\section{Materials and Methods}

\section{Materials}

HSC-T6 cells were purchased from the Cell Bank of Xiangya Medical College. High-glucose DMEM (HDMEM), trypsin, fetal bovine serum (FBS; Gibco), recombinant human TGF- $\beta 1$ ( $R \& D$ ), reagents for RNA extraction, primers for PCR, PCR kit (TaKaRa), rabbit anti-rat gremlin polyclonal antibody (Santa Cruz), 
rabbit anti-rat TGF- $\beta 1$ polyclonal antibody and mouse anti-rat a-SMA monoclonal antibody (Sigma) were used in the present study.

\section{Culture of HSC-T6}

The HSC-T6 stored at $-80^{\circ} \mathrm{C}$ were thawed at $37.5^{\circ} \mathrm{C}$ and then maintained in H-DMEM containing $10 \%$ FBS at $37^{\circ}$ $\mathrm{C}$ in a humidified environment with $5 \% \mathrm{CO}_{2}$. When the cell confluence reached nearly $70-80 \%$, cells were digested with $0.2 \%$ trypsin and passaged. Passaging was done again 3 days later. Cells in logarithmic growth phase were used in the following experiments.

\section{Preparation of Nef solution}

In brief, $25 \mathrm{mg}$ of Nef powder was dissolved in 340 $\mu$ mol of DMSO followed by addition of $3.1 \mathrm{~mL}$ of $\mathrm{H}-$ DMEM to prepare the primary Nef solution $(10 \mu \mathrm{mol} /$ L).

\section{Grouping}

When the cell confluence reached about $60 \%$, cells were maintained in H-DMEM containing 0.2\% FBS for 24 hours for synchronization. Then, these cells were divided into 3 groups: Group A (normal control group): Cells were maintained in H-DMEM containing $10 \%$ FBS; Group B (TGF- $\beta 1$ group): Cells were maintained in H-DMEM containing $10 \%$ FBS and $5 \mathrm{ng} / \mathrm{mL}$ recombinant human TGF- $\beta 1$; Group C (TGF- $\beta 1+$ Nef group): Cells maintained in H-DMEM containing $10 \%$ FBS and $5 \mathrm{ng} / \mathrm{mL}$ recombinant human TGF- $\beta 1$ were treated with Nef at different concentrations. On the basis of Nef concentrations (2.0, 4.0 and $8.0 \mathrm{mmol} / \mathrm{L})$, cells were further subdivided (Group C1-3).

\section{Effect of Nef on proliferation of HSCs}

Cells were seeded into 96-well plates at a density of 1.0 $\times 10^{5}$ cells $/ \mathrm{mL}(100 \mu \mathrm{L} /$ well $)$. When the cell confluence reached $60-70 \%$, cells were grown in serum-free medium for 24 hours. Following grouping, cells were maintained for another 24, 48 and 72 hours (5 wells in each group). CCK-8 was employed to detect the effect of Nef on the proliferation of HSCs.

Effect of Nef on mRNA expression of gremlin, TGF- $\beta 1$ and a- SMA in HSCS

Cells were seeded into 6-well plates at a density of $1.0 \times$ $10^{5}$ cells $/ \mathrm{mL}$ ( $2 \mathrm{~mL} /$ well; three wells in each group). When the cell confluence reached $70 \%$, cells were maintained in serum free medium for 24 hours. Then, these cells were divided into different groups and treated with correspondingly. Three wells were included in each well. At 48 hours after treatment, total RNA was extracted from the cells in each group according to the manufacturer's instructions, and the RNA content and purify were determined with a nucleic acid and protein analyzer. The A260/A280 was assured to be $1.8-2.0$. Then, $1 \mu \mathrm{L}$ of RNA was used for reverse transcription into cDNA. The primers were designed according to the sequences in the GenBank of NCBI. The primers were as follows: for gremlin: 5' CGCCATCCCCTCGCCTTACAA-3' (forward); 5'AACCCTCCTCGCTCACCGTCT-3' (reverse), the PCR conditions were $94^{\circ} \mathrm{C}$ for $2 \mathrm{~min}$ and 38 cycles of $94^{\circ} \mathrm{C}$ for $30 \mathrm{~s}, 60^{\circ} \mathrm{C}$ for $20 \mathrm{~s}$ and $72^{\circ} \mathrm{C}$ for $15 \mathrm{~s}$. For TGF $\beta 1$ : $5^{\prime}-$ TACCAACTACTGCTTCAGCTCCAC-3' (forward); 5'GTTGTGTTGGTTGTAGAGGGCA-3' (reverse), the PCR conditions were $94^{\circ} \mathrm{C}$ for $2 \mathrm{~min}$ and 28 cycles of $94^{\circ}$ $\mathrm{C}$ for $30 \mathrm{~s}, 57^{\circ} \mathrm{C}$ for $30 \mathrm{~s}$ and $72^{\circ} \mathrm{C}$ for $30 \mathrm{~s}$. For a-SMA: $5^{\prime}$ -GCTCTGTAAGGCGGGCTTTG-3' (forward); 5' ACGAAGGAATAGCCACGCTCA-3' (reverse), the PCR conditions were $94^{\circ} \mathrm{C}$ for $5 \mathrm{~min}$ and 30 cycles of $94^{\circ} \mathrm{C}$ for $30 \mathrm{~s}, 56^{\circ} \mathrm{C}$ for $30 \mathrm{~s}$ and $72^{\circ} \mathrm{C}$ for $45 \mathrm{~s}$. For $\beta$-actin: $5^{\prime}-$ CACCCGCGAGTACAACCTTC-3' (forward); 5' CCCATACCCACCATCACACC-3' (reverse), the PCR conditions were $94^{\circ} \mathrm{C}$ for $2 \mathrm{~min}$ and 22 cycles of $94^{\circ} \mathrm{C}$ for $30 \mathrm{~s}, 61^{\circ} \mathrm{C}$ for $30 \mathrm{~s}$ and $72^{\circ} \mathrm{C}$ for $30 \mathrm{~s}$. The PCR products were subjected to $2 \%$ agarose gel electrophoresis followed by analysis with gel image analysis system. The optical density was measured with BioSens SC810 and the expression of target genes was normalized to that of $\beta$-actin for semi-quantitative analysis.

\section{Detection of protein expression of gremlin, TGF- $\beta 1$ and} a- SMA by western blot assay

The culture medium was removed and HSC-T6 cells were washed in PBS thrice. These cells were digested in $0.2 \%$ trypsin and lysed for protein extraction. Then, 12 $\mu \mathrm{L}$ of lysate was subjected to SDS-PAGE and the protein was transferred onto PVDF membrane. After blocking for 1 hours, the membrane was treated with gremlin antibody (1:100), TGF- $\beta 1$ antibody (1:200), $\alpha-$ SMA antibody (1:200) or GAPDH (1:500) overnight. Then, the membrane was incubated with horseradish peroxidase conjugated secondary antibody for 1 hour followed by visualization with chemiluminescence reagent. Gel image system was employed to acquire the bands and BioSens SC810 for detection of optical density. The expression of target protein was normalized by that of GAPDH.

\section{Statistical analysis}

Quantitative data were expressed as mean \pm standard deviation, and statistical analysis was done with SPSS version 18.0. Homogeneity of variance test was done and comparisons among groups were done with one way analysis of variance followed by LSD test (homogeneity of variance) or Dunnett's T3 test (heterogeneity of variance). A value of $\mathrm{p}<0.05$ was considered statistically significant.

\section{Results}

After treatment with $5 \mathrm{ng} / \mathrm{mL}$ TGF- $\beta 1$, the proliferation of HSC-T6 cells was comparable to that in normal 
Table I

\begin{tabular}{|c|c|c|c|c|c|}
\hline \multicolumn{6}{|c|}{$\begin{array}{c}\text { Proliferation inhibition rate of HSC-T6 cells fol- } \\
\text { lowing Nef treatment }\end{array}$} \\
\hline $\begin{array}{l}\text { Time } \\
\text { (hours) }\end{array}$ & A & B & C1 (\%) & C2 (\%) & C3 (\%) \\
\hline 24 & - & - & $15.3 \pm 2.3$ & $20.8 \pm 1.7$ & $28.4 \pm 0.9$ \\
\hline 48 & - & - & $19.4 \pm 1.8$ & $35.8 \pm 1.7$ & $56.7 \pm 1.9$ \\
\hline 72 & - & - & $48.3 \pm 0.8$ & $62.3 \pm 1.8$ & $69.3 \pm 1.0$ \\
\hline
\end{tabular}

Note: Inhibition rate $=\left[\left(\mathrm{OD}_{\text {normal control }}-\mathrm{OD}_{\text {treatment }}\right) / \mathrm{OD}_{\text {normal control }} \times 100 \%\right]$

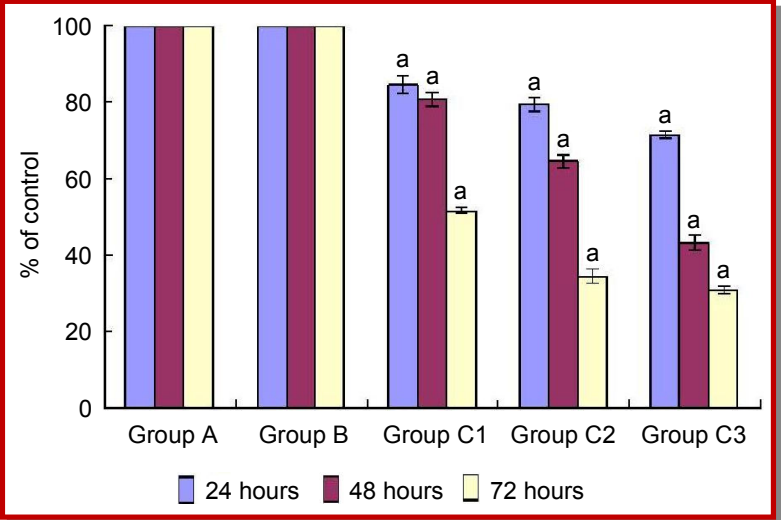

Figure 1: Inhibitory effect of Nef on proliferation of HSC-T6 cells a $\mathrm{p}<0.05$

control group $(\mathrm{p}>0.05)$. Following treatment with $\mathrm{Nef}$ at different concentrations $(2.0,4.0$ and $8.0 \mathrm{mmol} / \mathrm{L})$, the proliferation of HSC-T6 cells was markedly inhibited in a time dependent manner $(\mathrm{p}<0.05)$ (Table I, Figure 1).

Following TGF- $\beta 1$ treatment, the mRNA expression of gremlin, TGF- $\beta 1$ and $\alpha-S M A$ was markedly elevated $(\mathrm{p}<0.05)$. After treatment with Nef at different concentrations, the mRNA expression of gremlin, TGF- $\beta 1$ and a-SMA was dramatically reduced in a concentration dependent manner $(\mathrm{p}<0.05)$ (Table II).

Following TGF- $\beta 1$ treatment, the protein expression of gremlin, TGF- $\beta 1$ and $\alpha-S M A$ was markedly increased in HSC-T6 cells $(p<0.05)$. After treatment with Nef at different concentrations, the protein expression of

\section{Table II}

\begin{tabular}{|c|c|c|c|}
\hline \multicolumn{4}{|c|}{$\begin{array}{l}\text { Effect of Nef on mRNA expression of gremlin, TGF } \\
-\beta 1 \text { and } \alpha-S M A \text { in HSC-T6 cells }\end{array}$} \\
\hline $\begin{array}{l}\text { Gro } \\
\text { up }\end{array}$ & Gremlin & TGF- $\beta 1$ & a-SMA \\
\hline A & $0.649 \pm 0.0182$ & $0.255 \pm 0.0281$ & $0.061 \pm 0.0044$ \\
\hline B & $0.732 \pm 0.0217 \mathrm{a}$ & $0.382 \pm 0.0959 a$ & $0.078 \pm 0.0025^{a}$ \\
\hline $\mathrm{C} 1$ & $0.628 \pm 0.0671^{\mathrm{a}}$ & $0.285 \pm 0.1645^{\mathrm{a}}$ & $0.055 \pm 0.0006^{\mathrm{a}}$ \\
\hline $\mathrm{C} 2$ & $0.480 \pm 0.0173^{a}$ & $0.103 \pm 0.0829$ & $0.026 \pm 0.0008^{a}$ \\
\hline C3 & $0.249 \pm 0.00834^{a}$ & $0.067 \pm 0.0851^{\mathrm{a}}$ & $0.022 \pm 0.0005^{a}$ \\
\hline
\end{tabular}

Note: Inhibition rate $=\left[\left(\mathrm{OD}_{\text {normal control }}-\mathrm{OD}_{\text {treatment }}\right) / \mathrm{OD}_{\text {normal control }} \times 100 \%\right]$ gremlin, TGF- $\beta 1$ and a-SMA was dramatically reduced in a concentration dependent manner $(\mathrm{p}<0.05)$ (Table III, Figure 2).

There was positive correlation among the mRNA expression of gremlin, TGF- $\beta 1$ and a-SMA in HSC-T6 cells $(\mathrm{r}=0.658-0.679, \mathrm{p}<0.05)$.

\section{Discussion}

TGF- $\beta /$ Smad is an important signal pathway in the occurrence and development of hepatic fibrosis, and TGF- $\beta 1$ has been regarded as one of important factors promoting the hepatic fibrosis. Gremlin is a protein antagonist of bone morphogenesis and also involves in the hepatic fibrosis. Boers et al. (2006) found that the expression of gremlin was at a low level in quiescent and activated HSCs. The gremlin expression increases significantly once the HSCs transform into myofibroblasts (MF). There is evidence showing that, under pathological conditions such as diabetic nephropathy, hepatic fibrosis and idiopathic pulmonary fibrosis, the gremlin expression increases(Costello et al., 2010). Thus, gremlin involves in the tissue formation and organ fibrosis and can serve as a target in the treatment of fibrosis.

In recent years, some researchers investigate the biological effect of Nef. Studies have shown that Nef can inhibit the osteosarcoma cells (Zhang et al., 2012), increase the therapeutic efficacy of anti-tumor drugs (Huang et al., 2011), exert anti-inflammatory and antioxidative effects and confer pressure-lowering effect via dilating blood vessels (Jung et al., 2010). Zhao et al. (2010) found in in vitro and in vivo studies Nef could exert anti-fibrotic effect on bleomycin induced pulmonary fibrosis in a rat model via combating with inflammation and oxidation and inhibiting nuclear factor $-\mathrm{kB}$. Numerous studies have revealed the antifibrotic effect of Nef and Nef can improve the pulmonary fibrosis and renal fibrosis.

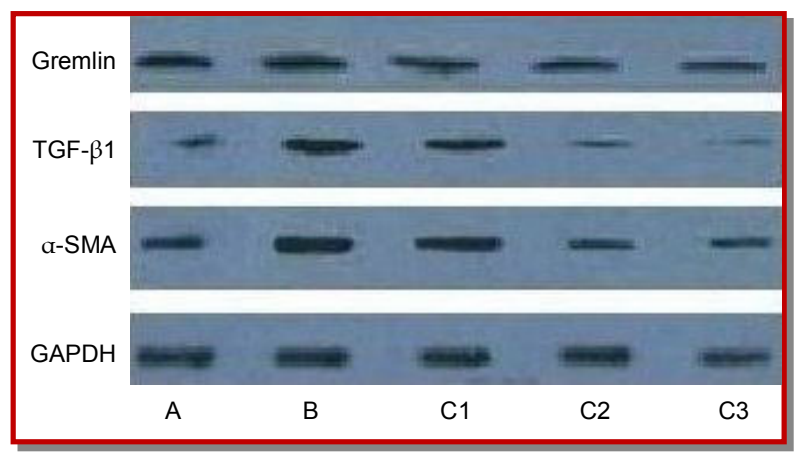

Figure 2: Protein expression of gremlin, TGF- $\beta 1$ and a-SMA in Western blot assay 
Table III

\begin{tabular}{|c|c|c|c|}
\hline \multicolumn{4}{|c|}{$\begin{array}{l}\text { Effect of Nef on protein expression of gremlin, TGF- } \\
\beta 1 \text { and } \alpha-S M A \text { in HSC-T6 cells }(x \pm s, n=5)\end{array}$} \\
\hline $\begin{array}{l}\text { Gro } \\
\text { up }\end{array}$ & Gremlin & TGF- $\beta 1$ & a-SMA \\
\hline A & $2.246 \pm 0.1007$ & $1.0140 \pm 0.0276$ & $2.156 \pm 0.1740$ \\
\hline B & $2.620 \pm 0.052$ & $1.168 \pm 0.0964^{a}$ & $2.156 \pm 0.1004^{\mathrm{a}}$ \\
\hline $\mathrm{C} 1$ & $1.532 \pm 0.0714^{\mathrm{a}}$ & $1.301 \pm 0.1654^{a}$ & $1.927 \pm 0.1130^{a}$ \\
\hline C2 & $1.772 \pm 0.0740 \mathrm{a}$ & $0.951 \pm 0.0832^{a}$ & $1.860 \pm 0.2274^{a}$ \\
\hline C3 & $0.922 \pm 0.0934^{a}$ & $0.944 \pm 0.0851^{a}$ & $1.317 \pm 0.2081^{\mathrm{a}}$ \\
\hline
\end{tabular}

Note: a $\mathrm{p}<0.05$ vs Group A

In the present study, following TGF- $\beta 1$ treatment, the HSCs lengthened and became spindle-shaped, but were adherent. After treatment with TGF- $\beta 1$ alone, the proliferation of HSC-T6 remained unchanged. This suggests the TGF- $\beta 1$ as an important pro-fibrotic factor has no significant influence on the proliferation of HSCT6 cells (Xu et al., 2005). Following Nef treatment, the proliferation of HSC-T6 cells was markedly inhibited. After treatment with Nef at $8.0 \mu \mathrm{mol} / \mathrm{L}$ for 48 hours, the inhibition rate was higher than $50 \%$. This suggests that Nef can signiticantly inhibit the proliferation of HSC-T6 cells. In addition, our results also demonstrated that exogenous TGF- $\beta 1$ could promote the expression of endogenous TGF- $\beta 1$, which is a major cause of vicious cycle in hepatic fibrosis. In the TGF- $\beta 1$ group, the mRNA expression of $\alpha$-SMA was significantly increased when compared with normal control group, which confirms the potent pro-inflammatory effect of TGF- $\beta 1$. In addition, TGF- $\beta 1$ could up-regulate the gremlin expression. In the TGF- $\beta 1$ group, the $\alpha-S M A$ expression was significantly increased when compared with the control group, accompanied by the upregulation of mRNA and protein expression of gremlin, which elucidates the correlation between gremlin and TGF- $\beta$ signaling pathway. The changes in gremlin expression were positively related to the expression of TGF- $\beta 1$ and $\alpha$-SMA, which further demonstrates the correlation between gremlin and hepatic fibrosis. Thus, we speculate that TGF- $\beta 1$ is an inducer of gremlin expression and gremlin may involve in the hepatic fibrosis and serve as a new target for the treatment of hepatic fibrosis.

On the basis of study on rat HSCs, we investigated the effect of Nef on hepatic fibrosis. Our results showed Nef can inhibit the proliferation and activation of HSCs and reduce the expression of gremlin, TGF- $\beta 1$ and $\alpha-$ SMA. Our findings demonstrate the protective effect of Nef on hepatic fibrosis but the exact mechanism requires to be further studied. Thus, studies on the antifibrotic effect of Nef may provide evidence for the treatment of hepatic fibrosis.

\section{References}

Boers W, Aarrass S, Linthorst C, Pinzani M, Elferink RO, Bosma P. Transcriptional profiling revealsnovel markers of liver fibrogenesis: Gremlin and insulin- like growth factor binding proteins. J Biol Chem. 2006; 281: 16289-95.

Costello CM, Cahill E, Martin F, Gaine S, McLoughlin P. Role of gremlin in the lung: Development and disease. Am J Respir Cell Mol Biol. 2010; 42: 517-23.

Ding H, Shi J, Wang Y, Guo J, Zhao J, Dong L. Neferine inhibits cultured hepatic stellate cell activation and facilitates apoptosis: A possible molecular mechanism. Eur J Pharmacol. 2011; 650: 163-69.

Huang C, Li Y, Cao P, Xie Z, Qin Z. Synergistic effect of hyperthermia and neferine on reverse multidrug resistance in adriamycin-resistant SGC7901/ADM gastric cancer cells. J Huazhong Univ Sci Technolog Med Sci. 2011; 31: 488-96.

Jung HA, Jin SE, Choi RJ, Kim DH, Kim YS, Ryu JH, Kim DW, Son YK, Park JJ, Choi JS. Anti-amnesic activity of neferine with antioxidant and anti-inflammatory capacities, as well as inhibition of ChEs and BACE1. Life Sci. 2010; 87: 420-30.

Sethi A, Jain A, Zode GS, Wordinger RJ, Clark AF. Role of TGFbeta/Smad signaling in gremlin induction of human trabecular meshwork extracellular matrix proteins. Invest Ophthalmol Vis Sci. 2011; 52: 5251-59.

Tacke F, Weiskirchen R. Liver fibrosis-pathogenesis and novel therapeutic approaches. Internist (Berl). 2010; 51: 21-29.

Xu L, Hui AY, Albanis E, Arthur MJ, O'Byrne SM, Blaner WS, Mukherjee P, Friedman SL, Eng FJ. Human hepatic stellate cell lines, LX-1 and LX-2: New tools for analysis of hepatic fibrosis. Gut 2005; 54: 142-51.

Zhang X, Liu Z, Xu B, Sun Z, Gong Y, Shao C. Neferine, an alkaloid ingredient in lotus seed embryo, inhibits proliferation of human osteosarcoma cells by promoting p38 MAPK-mediated p21 stabilization. Eur J Pharmacol. 2012; 677: 47-54.

Zhao L, Wang X, Chang Q, Xu J, Huang Y, Guo Q, Zhang S, Wang W, Chen $X$, Wang J. Neferine, a bisbenzylisoquinline alkaloid attenuates bleomycin-induced pulmonary fibrosis. Eur J Pharmacol. 2010; 627: 304-12. 